\title{
On the Production-education Production-based Construction of Teaching Materials on Animation in Higher Vocational Colleges
}

\author{
Yanchai Zhang ${ }^{1}$, Wenfeng $\mathrm{Li}^{2}$ and Yingbin $\mathrm{Fu}$ \\ Qionghai City, Hainan province China Fu Road No. 128 Hainan College of Software Technology \\ 70737632@qq.com, 31693878@qq.com, 54833340@qq.com
}

\begin{abstract}
Keywords: Higher vocational college; Production-education integration; Development of teaching materials
\end{abstract}

\begin{abstract}
Production-education integration is an important means and effective channel, through which the "win-win situation" and harmonious development of schools and enterprises can be implemented. The Animation Major of Hainan College of Vocation and Technique is taken as an example in this paper, in which the practical experience of developing teaching materials for specialized courses on animation in higher vocational colleges is integrated. Furthermore, the characteristics of the existing teaching materials on animation in higher vocational colleges are analyzed, and the new train of thought of constructing the teaching materials is proposed. The production of commercial animation is considered as the principal line, and the production of animation is divided into several links. On the basis of production-education integration, teaching materials on animation that include complete projects are developed to create characteristic and original teaching materials of superior quality, and promote the construction and implementation of the scientific pattern of production-education integration in higher vocational colleges.
\end{abstract}

\section{Introduction}

It is indicated in The State Council's Decision of Accelerating the Development of Modern Vocational Education that the characteristics of vocational schools should be emphasized, the school-enterprise cooperation should be reinforced, and education should play a synergetic role in this. Furthermore, production-education integration should be insisted on, and education and teaching activities which integrate teaching, learning and practical training should be intensified, and the integration of learning and working should be further deepened, so as to cultivate a group of application-oriented talents who are equipped with certain scientific and theoretical knowledge and favorable practical skills.

The animation industry has yielded rapid development in China in recent years. However, questions like the deficiency of originality and talents in local animation works have restricted the development of the animation industry in China. Under this background, the animation major in higher vocational colleges has experienced several years of rapid development and entered the stage, in which it should reinforce the connotation construction, intensify school-enterprise cooperation and cultivate qualified talents specialized in animation. Next, the animation major in Hainan College of Software Technology is taken as an example, and the philosophy of production-education integration is integrated to probe into the author's reflection on the construction of teaching materials on animation.

Animation Design and Production, which is a provincial-level characteristic major in Hainan Province, was made available in Hainan College of Software Technology in 2006. From 2014 to 2016, its students have participated in various national-level competitions, and been awarded three First Prizes, one Second Prize and one Third Prize in national vocational skill competitions. These cannot be achieved without curriculum reform and the reform of the teaching pattern of production-education integration. Based on the philosophy of production-education integration, students are cultivated to be interested in the major in accordance with the requirements of 
innovative and characteristic teaching of animation. Thus, students can transform from the mode of passive learning to independent learning.

\section{The Connotation and Significance of Production-education Integration in Higher Vocational Colleges}

1) The Connotation of Production-education Integration in Higher Vocational Colleges

Production-education integration integrates production and education dynamically to implement the dynamic coordination and integration of theoretical teaching and production practice. The essential mission of production-education integration is to integrate educational resources and enhance the quality of education through the form of innovative education to raise students' job qualification and practical skills, and satisfy the social demands. Meanwhile, production-education integration is conducive to the technological innovation and efficiency improvement of enterprises, and the promotion of rapid corporate development. Production-education integration is an important means and effective channel, through which the "win-win situation" and harmonious development of schools and enterprises can be implemented. It is also a concentrated reflection of higher vocational colleges' educational value, social value and economic value.

2) The Significance of Production-education Integration in Higher Vocational Colleges

Production-education integration combines enterprises, schools, government and social organizations to conduct resource integration and optimal configuration. Thus, they can learn from others' strong points to offset their own weaknesses, and complement each other's advantages. By virtue of production-education integration, the capability of social practice can be enhanced, the transformation of education can be promoted, and teachers' qualities can be raised, and simultaneously, the economic development can be driven. Production-education integration is a new form and train of thought of higher vocational education, and an innovation of higher vocational education. Under this pattern, the curriculum provision, teaching content and evaluation mode of higher vocational colleges are confronted with reforms. Production-education integration also proposes new requirements and challenges to teachers. Only by acquiring continuously self-improvement can these teachers adapt themselves to the new situation in higher vocational colleges.

\section{Reflection on the Construction of Animation Teaching Materials under the Philosophy of Production-education Integration}

\section{Characteristics of Existing Teaching Materials on Animation}

Through the dramatic development of animation in recent years, there are a large number of teaching materials on animation. However, there's a most prominent characteristic---the severe disconnection between teaching materials and practice. Many cases are old-fashioned and simple, and consequently, they fail to attract students' interest, and the effect of learning cannot reach the teaching objective or requirement. The majority of teaching materials manifest a deficiency of pertinence and practicability. Since cases in the teaching materials are basically in sections and chapters, they are relatively poor in mutual connection and they cannot reflect the procedure of animation creation. Consequently, students hold ambiguous objectives during the study and fail to create animations that are consistent with the market demands. In addition, the cultivated students cannot adapt themselves to the requirements of the enterprises.

Moreover, there are many teaching materials which introduce fundamental software, but the number of original and high-quality teaching materials is quite limited. It's quite difficult to find teaching materials that involve originality from such early settings as screenplay, original drawing, scene design, character setting, storyboard design and action design to the middle production and the later composition. Under this circumstance, the effect of teaching is self-evident.

2. Principles of Animation Teaching Material Construction Based on Production-education integration 
The educational objective of higher vocational colleges is to cultivate application-oriented talents which can adapt to the demands of the socialist market for the society. Therefore, the teaching materials must be consistent with the characteristics of education in higher vocational colleges, and the objective of the cultivation of professional talents must be closely integrated, and the necessary vocational knowledge and capabilities must be reasonably arranged. During the construction of teaching materials, theories and practice must be integrated, and operation and practical training must be reinforced to help students achieve mastery in the cultivation of vocational skills. The curriculum content should be established in accordance with the working procedure, and the knowledge must be arranged under the sequence by difficulty, so that students can complete some projects progressively.

The animation major of Hainan College of Software Technology has been carrying out school-enterprise cooperation energetically and emphasizing production-education integration. In light of students' characteristics, we have been transforming the teaching concepts, and transforming the teaching content into project-oriented, teaching achievements into project-oriented and teaching management into enterprise-oriented. We brought Happy Puppy, a series high-definition three-dimensional animation by CCTV and Shi Hu's Legend, an animation project with the local characteristic of Qionghai planned and produced by Shi Hu Studio in our teaching. During the teaching, we consider the market as our orientation, and the animation industry as our support to integrate production and education, increase the consistency with industry, and implement module-based teaching guided by animation production. We have been reforming the classroom system, integrating teaching resources and innovating teaching methods. In addition, we are in the research and development of a set of teaching materials that's suitable for the teaching of animation---series teaching materials for original animation creation, which mainly includes Early Creation of Original Animation Short Films, Scene Design of Original Animation Short Films, Role Design of Original Animation Short Films, Storyboard Design of Original Animation Short Films, Action Design of Original Animation Short Films, Introduction to Proficiency in MAYA Three-dimensional Animation Practice Manual. The early, middle and later stage are all guided by original animation projects. The process of animation production is integrated into teaching cases, which breaks the previous structure of teaching materials by chapters and sections. Through the analysis of the animation production, this process is divided into several links. In accordance with these links, knowledge modules are constructed accordingly. Students can grasp one link of animation production through the study of one module. In accordance with the difficulty and progressive relationship of the knowledge modules, students can grasp the overall process of animation production step by step.

3. The Procedure of Teaching Materials Development

In accordance with the principles of the development of teaching materials, Introduction to Proficiency in MAYA Three-dimensional Animation Practice Manual is taken as an example to demonstrate the development of teaching materials. The animation project Pencil's Story is taken as a case in the teaching material. In this animation, enterprise teachers and frontline teachers write the play through concerted endeavors, and professional teachers draw the storyboards. In accordance with enterprises' criteria of assessment, relevant post and creation procedure is set up. An emphasis is placed on the cultivation of vocational skills, hoping to transform the teaching pattern into project-oriented and arrange the teaching content under the sequence by difficulty. Thus, students can grasp the procedure of animation production, and penetrate the various modules into the overall training, through which students can learn required skills and knowledge in practical projects. Please see the detailed flow chart of the development below. 


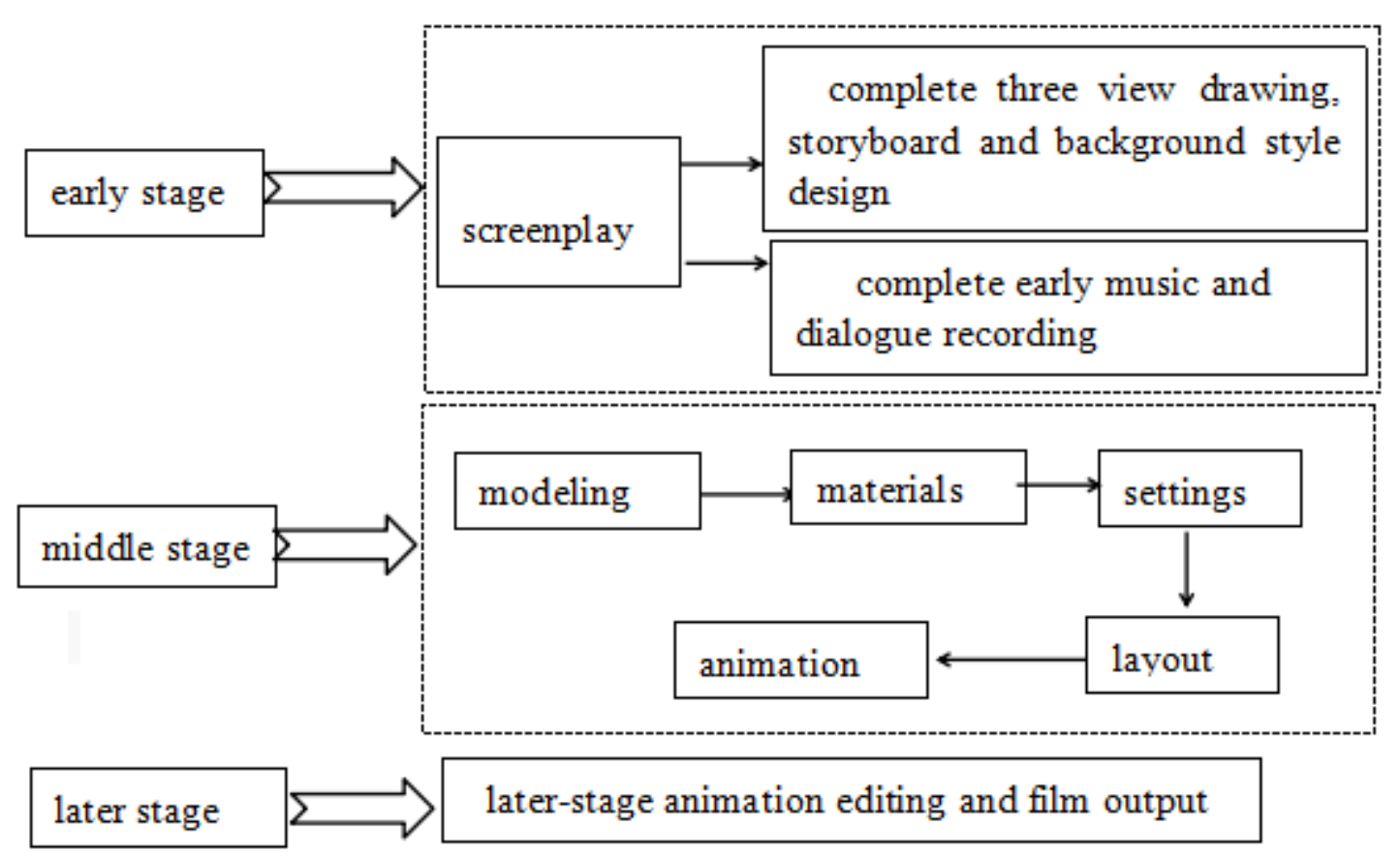

Figure 1

The teaching material Introduction to Proficiency in MAYA Three-dimensional Animation Practice Manual takes project as its orientation, and organizes teaching under the task-driven pattern. It combines teaching with practical operation, and integrates each knowledge point in the practical operation, and emphasizes the improvement of students' ability of operation, creation and innovation. The instruction proceeds step by step to integrate education and learning, through which students can get started very quickly and grasp it with ease. The book is divided into nine projects.

Each project is included in the design process, which is compiled in accordance with the modules and tasks of the project. It mainly includes such links as model, setting, material, layout, animation and later-stage composition. Since the case procedure is integral, the effect is intuitive, students can be substantively motivated in study.

\section{Conclusion}

The animation major in higher vocational schools has been continuously attempting various professions and curriculum reforms, hoping to adapt themselves to the continuous development of the animation industry and cultivate talents with vocational skills that are urgently needed in enterprises. As an important link of reform, characteristic original teaching materials on animation have attracted increasing attention. In the cultivation of vocational skills, school-enterprise cooperation should be relied on, post requirements and working procedure should be reflected in teaching materials and teaching, and talents specialized in animation that can satisfy with corporate demands should be cultivated.

\section{References}

[1] Cuiyan, On the Characteristic Major Construction in Higher Vocational Colleges [J] 2008. Academic journal of Shaanxi Railway Institute

[2] Liu Shangbing, Practical Establishment of School-enterprise Cooperation Mechanism with the Coexistence of Multiple Patterns. 2012 Academic journal of Fujian Agriculture and Forestry University

[3] Deng Biqin, On the Current Situation and Development of Chinese Animation Education [J], 2009, 10 Vocational Education Research 
[4] Zeng Lingqin, On the Construction of Teaching Materials in Higher Vocational Colleges [J]. 2007 Chinese Vocational Education

[5] Curriculum Implementation and Teaching Reform [M], 2005 (6) Sichuan University Press

[6] Reflections on the Composition and Publishing of Animation Teaching Materials in Higher Vocational Colleges, 2011 (5) Lvjiang 